\title{
Yellow-cedar and western redcedar ecophysiological response to fall, winter and early spring temperature conditions
}

\author{
Steven C. Grossnickle ${ }^{\mathrm{a} *}$, John H. Russell ${ }^{\mathrm{b}}$ \\ a CellFor Inc., PO Box 133, Brentwood Bay, B.C., Canada V8M 1R3 \\ ${ }^{b}$ British Columbia Ministry of Forests, Cowichan Lake Research Station, Box 335, Mesachie Lake, B.C., Canada, V0R 2N0
}

(Received 17 January 2005; accepted 23 September 2005)

\begin{abstract}
Western redcedar (Thuja plicata Donn) and yellow-cedar (Chamaecyparis nootkatensis (D. Don) Spach) populations originating from an elevation zone where these two species naturally coexist were monitored to define their performance patterns in response to seasonal temperature conditions within the fall, winter and early spring field conditions of the Pacific Northwest coastal forest region. Western redcedar and yellow-cedar populations were measured for changes in growth rhythms, photosynthetic patterns and freezing tolerance. Net photosynthesis $\left(\mathrm{P}_{\mathrm{n}}\right)$ for both species was directly related to minimum air temperature that occurred during the prior evening, though no population differences were detected within each species. Photosynthesis was greater in western redcedar, than yellow-cedar when minimum air temperature was above freezing. Freezing temperatures from $\sim 0$ to $-5^{\circ} \mathrm{C}$ caused a greater reduction in photosynthesis for western redcedar, though not a complete cessation of photosynthetic capability in either species. Freezing tolerance increased at a moderate rate in the fall as mean air temperature declined for both species when their shoot systems were still active, with freezing tolerance increasing at a rapid rate when shoot systems showed no mitotic activity. No shoot growth or mitotic activity was detected in shoot tips of both western redcedar and yellow-cedar when mean air temperature decreased to $4{ }^{\circ} \mathrm{C}$ for the previous week. No population differences, within each species, were detected in the development of fall freezing tolerance. Yellow-cedar obtained a slightly greater level of freezing tolerance when fall temperatures were $<4{ }^{\circ} \mathrm{C}$. Both species had a loss of freezing tolerance as mean air temperature increased in late winter. Shoot growth resumed in both species in late winter when mean air temperature increased to 6 to $6.5^{\circ} \mathrm{C}$. The resumption of shoot growth resulted in a faster loss of freezing tolerance for western redcedar compared to yellow-cedar.
\end{abstract}

Thuja plicata / Chamaecyparis nootkatensis / ecophysiological response / temperature

Résumé - Réponses écophysiologiques de Thuja plicata Donn et de Chamaecyparis nootkatensis (D. Don) Spach aux conditions thermiques automnales, hivernales et printanières. Des populations de Thuja plicata Donn et de Chamaecyparis nootkatensis (D. Don) Spach provenant d'une zone d'altitude où ces deux espèces coexistent ont été suivies pour définir leurs types de performances en réponse aux conditions thermiques saisonnières de l'automne, de l'hiver et du début du printemps dans la région forestière côtière du Nord Ouest Pacifique. Les populations de Thuja plicata et de Chamaecyparis nootkatensis ont été mesurées pour étudier les variations dans les rythmes de croissance, les types d'activité photosynthétique et la tolérance au gel. Pour les deux espèces, la photosynthèse nette (Pn) était directement liée au minimum de température du soir précédent, bien que des différences n'aient pas été mises en évidence entre populations dans chacune des espèces. La photosynthèse était plus élevée chez Thuja plicata que chez Chamaecyparis nootkatensis lorsque la température minimum était au-dessus de zéro degré. Les températures glaciales de -0 à $-5^{\circ} \mathrm{C}$ induisent la réduction la plus importante de la photosynthèse chez Thuja plicata, quoiqu'il n'y ait pas un complet arrêt de la capacité photosynthétique chez l'une ou l'autre des espèces. Pour les deux espèces, la tolérance au gel s'accroît en automne : modérément avec l'abaissement de la température moyenne de l'air quand leurs systèmes de pousse étaient encore actifs, rapidement lorsque leurs systèmes de pousses ne présentent plus d'activité mitotique. Aucune croissance des pousses ou activité mitotique n'a été notée chez Thuja plicata et Chamaecyparis nootkatensis lorsque la température moyenne de l'air baisse de $4{ }^{\circ} \mathrm{C}$ pendant le jour précédent. Aucune différence n'a été mise en évidence entre populations pour chacune des espèces, pour ce qui concerne le développement de la tolérance au gel. Thuja plicata a présenté un niveau de tolérance au gel légèrement plus grand quand en automne, les températures étaient $<4{ }^{\circ} \mathrm{C}$. Les deux espèces avaient une perte de tolérance au gel avec l'accroissement de la température de l'air en fin d'hiver. La croissance des pousses a repris en fin d'hiver lorsque la température moyenne augmentait jusqu'à 6 à $6,5^{\circ} \mathrm{C}$. La reprise de la croissance des pousses a été le résultat d'une perte plus rapide de la tolérance au gel chez Thuja plicata par comparaison avec Chamaecyparis nootkatensis.

Thuja plicata / Chamaecyparis nootkatensis / réponse écophysiologique / température

\section{INTRODUCTION}

The Pacific Northwest coastal region is dominated by coniferous forests that extend from southwestern Alaska, through
British Columbia, and south into northern California. Western redcedar (Thuja plicata Donn) and yellow-cedar (Chamaecyparis nootkatensis (D. Don) Spach) are both members of the Cupressaceae, or cypress, family and are found within this forested

\footnotetext{
* Corresponding author: sgrossnickle@ shaw.ca
} 
region. These forests exist in a region that is typically exposed to wet and mild winters. Western redcedar is usually confined to lower elevation (i.e., below $1400 \mathrm{~m}$ ) forests where freezing temperatures occasionally occur, but rarely below $-5{ }^{\circ} \mathrm{C}$ during the winter months $[10,17]$. Yellow-cedar is found near sea level in Alaska and at mid to high elevations (i.e., 600 to $2300 \mathrm{~m}$ ) in the southern half of its range where air temperatures do not typically fall below $-30{ }^{\circ} \mathrm{C}$ during the winter $[10,17]$. Thus, there are portions of this coastal region where western redcedar and yellow-cedar coexist in the same forests.

The wet and mild fall-winter temperature condition of the Pacific Northwest coastal forests allows some conifer species to have unique seasonal morphological development and physiological patterns. For example, western redcedar and yellowcedar do not have a fixed fall-winter shoot growth pattern. These species typically have inactive shoot growth during the fall and winter season, though they have an opportunistic form of growth that responds to seasonal temperature conditions [35]. Conifer species, such as western redcedar and yellowcedar, are believed to have a distinct advantage under the current climatic conditions of this region because photosynthesis is responsive to temperature changes during the fall and winter months [53]. In addition, mild winter temperature conditions found in coastal forest regions allow species lacking a specialized resting bud to attain only a moderate level of freezing tolerance in direct response to temperature changes [41]. By defining the physiological response of a species to specific site environmental conditions, one provides a means to understand the biological basis for adaptability of a species to site [7]. Thus, it is hypothesized that seasonal temperature conditions found within these coastal coniferous forests can have a strong effect on the ecophysiological response of western redcedar and yellow-cedar during the fall, winter and early spring period.

This study determined the shoot growth pattern, plus photosynthetic and freezing tolerance patterns of western redcedar and yellow-cedar populations during fall, winter and early spring. The experimental objective was to determine whether western redcedar and yellow-cedar populations originating from the same elevation zone differ in their fall, winter and spring acclimation process in response to seasonal temperature conditions. Knowing how fall-winter-early spring climatic conditions affect the performance of western redcedar and yellow-cedar will improve the understanding of these species niche within the Pacific Northwest coastal forests. This information can enable practitioners to develop effective adaptive forest management practices and the scientific community to have a better appreciation of western redcedar and yellowcedar responses when modeling for potential climate change.

\section{MATERIALS AND METHODS}

\subsection{Plant material}

Western redcedar (Thuja plicata Donn) and yellow-cedar (Chamaecyparis nootkatensis (D. Don) Spach) experimental material originated from two elevational locations (western redcedar: 570 and $900 \mathrm{~m}$; yellow-cedar: 570 and $1100 \mathrm{~m}$ ) on Mt. Washington, British Columbia, Canada $\left(49^{\circ} 6^{\prime} \mathrm{N}, 125^{\circ} 3^{\prime} \mathrm{W}\right)$. Cuttings were collected from the lower crown from six young natural trees of each species at each elevation in September of 1993 and rooted at Cowichan Lake Research Station under standard cultural practices [40]. Five random rooted cuttings from each clone were transplanted into 1 gallon pots and grown under a standard greenhouse regime during the 1994 season. All donor plants were hedged during the growing season. Cuttings were then retaken in the fall of 1994 from each of the five donor plants per clone and rooted under standard cultural practices in Spencer LeMaire Hilson's ${ }^{\mathrm{TM}}$ containers using a completely randomized block design with three replications of up to 63 cuttings per clone per block. Rooted cuttings were cultured as $1+0$ container-grown plants throughout the 1995 growing season. The above procedure assisted in minimizing maturation-related effects and both "C-effects" (between clone common environments) and "c-effects" (within clone common environments) that can influence rooting, stock quality and growth [40].

\subsection{Field design}

Rooted cuttings were placed on two coastal sites $\left(49^{\circ} 2^{\prime} \mathrm{N}, 123^{\circ} 7^{\prime} \mathrm{W}\right.$ at $50 \mathrm{~m}$ and $1000 \mathrm{~m}$ ) in late summer. Each test population was comprised of one-year-old rooted cuttings with an even distribution from six clones for each population of each species. Rooted cuttings were transferred into 415D Styroblock ${ }^{\mathrm{TM}}$ (Beaver Plastics) at $160 \mathrm{~mL}$ volume with a completely randomized experimental design with 20 rooted cuttings from each of six clones for each of the two source locations within each species (i.e., a total of 480 potted plants). The exact same experimental design was located on two field sites with plants on both sites monitored for shoot growth and freezing tolerance patterns, in the fall (until snow covered the high elevation site), while photosynthesis, shoot growth and freezing tolerance were monitored throughout winter and spring on the low elevation site. Within this experimental population, rooted cuttings were randomly selected for morphological and physiological measurements. The same randomly selected rooted cuttings were repeatedly measured for morphological and gas exchange measurements. Freezing tolerance measurements were taken on a rotating population of rooted cuttings with an equal representation from each clone across sample populations. Styroblocks ${ }^{\mathrm{TM}}$ of edge seedlings were placed around the test population. Total size of field trials were $\sim 16 \mathrm{~m}^{2}$. This small field trial size minimized any rooted cuttings exposure to microclimatic differences throughout the trial.

Containers were covered with 2.5 to $5.0 \mathrm{~cm}$ of bark mulch to minimize any root damage due to seasonal freezing or drought events. Rooted cuttings were watered weekly during the fall to minimize exposure to drought conditions. Rooted cuttings were exposed to the normal seasonal decline in fall photoperiod and temperature on both field sites, while the low elevation site was exposed to winter through early spring seasonal photoperiod and temperature patterns. The high elevation site was covered with snow after Julian day 320 and was under snow throughout the remainder of the study. Air (at $25 \mathrm{~cm}$ ) temperature was monitored continuously on field sites. Rooted cuttings were allowed to acclimate for two weeks prior to the start of any measurements.

At time of field establishment, the western redcedar populations had an overall height and diameter of $31.4 \mathrm{~cm}$ and $3.8 \mathrm{~mm}$, respectively and the yellow-cedar populations had an overall height and diameter of $28.6 \mathrm{~cm}$ and $3.7 \mathrm{~mm}$, respectively

\subsection{Shoot growth}

The point at which shoot growth ceased was measured by mitotic activity for both species from late September through early November 1995 , every other week. Shoot growth assessments were repeated on the same rooted cuttings throughout the fall. Resumption of shoot growth in the spring was determined by measuring changes in shoot length from mid February through March, 1996. Each elevational 
population for each species had 12 rooted cuttings (i.e., 2 rooted cuttings from each of 6 clones were measured to provide equal representation across the sample population) randomly selected and then marked for shoot growth measurements. At the beginning of the experiment, a selected location on the shoot leader was marked with a nontoxic compound to facilitate consistent measurement of new terminal shoot development.

Mitotic activity determined fall cessation of shoot growth and was measured on lateral shoot tips from the upper portion of rooted cuttings [27]. Shoot tips were collected and fixed immediately in McClintock's solution [25]. Shoot apices were hydrolyzed in $1 \mathrm{M} \mathrm{HCL}$ overnight and then stained with Schiff's reagent (Feulgen reaction). These shoot tips were squashed on a microscope slide, underneath a cover-slip, and then mitotic activity was determined (i.e., whether or not cells were in the interphase).

\subsection{Gas exchange}

Photosynthetic response was assessed on a weekly basis starting in early September, 1995, and continued until mid April, 1996. Net photosynthesis $\left(\mathrm{P}_{\mathrm{n}}\right)$ was measured on rooted cuttings of both species at the low elevation field site. Net photosynthesis was measured with a LI-6200 (LI-COR Inc.) gas exchange system and a 1/4 L (LI-6200-13) sample chamber cuvette. Additional gas exchange measurements were taken, when possible, after all natural freezing events. Gas exchange measurements were taken at 9:00 AM under a shelter at the field site. During measurements, rooted cuttings were exposed to ambient temperature, humidity and $\mathrm{CO}_{2}$ conditions under a point light source of $1000 \mu \mathrm{mol} \mathrm{m}-2 \mathrm{~s}^{-1}$ photosynthetically active radiation to produce a maximum $P_{n}$ reading. Each measurement was $30 \mathrm{~s}$ in length to reduce variation between ambient and chamber environments. Gas exchange measurements were taken from two to four hours after sunrise. There were six gas exchange replicates per population for each species (i.e., 1 plant from each of 6 clones from each of two populations for each species resulted the measurement of 24 rooted cuttings).

\subsection{Freezing tolerance}

Freezing tolerance was measured on a bi-weekly basis from early September, 1995, through mid April, 1996. Freezing tolerance of foliage was determined by the freeze-induced electrolyte leakage (FIEL) procedure [4]. Foliage was removed from branches on the middle third of the stem from two rooted cuttings from each of six clones for each population of each species to provide equal representation across the sample population. Samples were collected from tertiary lateral branch foliage; foliage segments were cut at both ends into $0.5 \mathrm{~cm}$ lengths, washed in de-ionized water and pooled from both rooted cuttings for each clone. These foliage segments were transferred, in random groups of 12 , to glass culture tubes containing $0.5 \mathrm{~mL}$ de-ionized water. One tube from each clone was stoppered and placed in ice water as a control at $1^{\circ} \mathrm{C}$. Four tubes from each clone were placed in an ethanol bath at $-2{ }^{\circ} \mathrm{C}$, cooled by a refrigeration system (Forma Scientific MC-8-80). Water in all tubes in the ethanol bath was nucleated simultaneously with ice crystals after $0.5 \mathrm{~h}$, and tubes were stoppered. The ethanol bath was then cooled at $5{ }^{\circ} \mathrm{C} \mathrm{h}^{-1}$.

Four temperatures were selected to bracket the anticipated 50\% tissue electrolyte leakage value. When one of the selected temperatures was reached, tubes for each species were removed and contents were allowed to thaw in ice water. After contents of all tubes had thawed, $5.5 \mathrm{~mL}$ of de-ionized water was added to each tube. Tubes were then stoppered and placed on a $100 \mathrm{rpm}$ shaker at $24^{\circ} \mathrm{C}$ for $20-24 \mathrm{~h}$. Conductivity of the solution in each tube was measured after incubation. Tubes were then placed in a $90{ }^{\circ} \mathrm{C}$ water bath for 15 min to induce maximum tissue injury and conductivity was re-measured after an additional $20 \mathrm{~h}$ on a $100 \mathrm{rpm}$ shaker at $24^{\circ} \mathrm{C}$.
Measured FIEL values were interpreted as an index of injury (II) $[6,8]$ with modifications made by [4]. Test results were reported as percent II calculated by the following formula:

$$
\mathrm{II}=\left\{1-\left(\frac{1-T_{1} / T_{2}}{1-C_{1} / C_{2}}\right)\right\} \times 100
$$

where $T_{1}$ and $T_{2}$ are the conductivity of treatment tubes after freezing and after boiling, respectively, and $C_{1}$ and $C_{2}$ are the conductivity of control tubes before and after boiling, respectively. Temperature at which $50 \%$ foliage electrolyte leakage occurred (i.e., $\mathrm{LT}_{50}$ ) was then calculated for each species using a linear regression equation derived from injury indices measured at four subzero temperatures.

\subsection{Data analysis}

Physiological and shoot growth parameters measured across seasons were related to the following site temperature parameters: (1) $P_{n}$ readings were related to minimum air temperature from the previous night period, (2) cessation and the resumption of shoot growth were related to mean air temperature for the previous seven day period, and (3) freezing tolerance readings were related to mean air temperature for the previous seven day period. Freezing tolerance measurements taken in the fall on the high elevation site were combined with low elevation site data to capture species response to temperature conditions down to $0{ }^{\circ} \mathrm{C}$. The dynamic nature of gas exchange and freezing tolerance patterns to seasonal temperature conditions requires a phenomenological (i.e., descriptive) modeling approach to capture a representative response pattern to the seasonal temperature range. One can increase the predictive power of performance assessment; in this case species variation of gas exchange [16] and freezing tolerance [49] patterns, by developing phenomenological models with the most limiting seasonal environmental parameter (i.e., temperature). Regression models were developed to relate physiological response to these various temperature parameters [26]. Models with all components (i.e., transformations of various temperature parameters) significantly contributing $(p=0.05)$, and with the highest $r^{2}$ values, were considered to have the best fit. Models for each physiological parameter, for each population within each species, and differences between species, in response to various temperature parameters are specified in the corresponding figure. These models qualitatively describe the range of variation between sampled populations physiological response as absolute values.

Physiological response to various temperature parameters were analyzed by either an analysis of variance or covariance analysis for population differences for each species, and population differences between species. No analysis was conducted on cessation and resumption of shoot growth because it occurred at the same time for both species and for populations within each species. When relationships between physiological parameters with temperature parameters were nonlinear, these parameters were transformed in logarithmic fashion to obtain a linear relationship with the covariant (temperature parameter). Data transformation remedies not only deviations from linearity, but also tends to simultaneously remove non-normality and hederoscedasticity to allow a test of significance on nonlinear data [24]. The general statistical model used for covariance analysis was:

$$
Y_{\mathrm{ijk}}=\mu+C_{\mathrm{i}}+W_{\mathrm{j}}+C W_{\mathrm{ij}}+\varepsilon_{\mathrm{ijk}}
$$

where $Y_{\mathrm{ijk}}$ is the physiological measurement, $\mu$ the population mean ( 2 species $\times 2$ elevations), $C_{\mathrm{i}}$ is the effect of ith population, $W_{\mathrm{j}}$ is the effect of the jth covariant (temperature parameter), $C W_{\mathrm{ij}}$ is the interaction of the ith population with the jth covariant, $\varepsilon_{\mathrm{ijk}}$ is the random effect. This model was first run using the general linear model procedure to test slope homogeneity before an analysis of covariance was 
performed using an ANCOVA procedure. Population differences within a species along with population differences between species for various physiological parameters were then determined using a Tukey's HSD multiple comparison analysis procedure. All statistical analyses procedures used the Statistics, Systat ${ }^{\circledR}$ for Windows ${ }^{\mathrm{TM}}$ programs (Version 5.0) [55].

\section{RESULTS AND DISCUSSION}

\subsection{Net photosynthesis}

Net photosynthesis $\left(\mathrm{P}_{\mathrm{n}}\right)$ had a general seasonal pattern of declining $\mathrm{P}_{\mathrm{n}}$ rates during the fall for both western redcedar and yellow-cedar, with consistently low $\mathrm{P}_{\mathrm{n}}$ rates during mid winter, followed by increasing $P_{n}$ rates in late winter and early spring (data not shown). This seasonal pattern of $P_{n}$ for western redcedar and yellow-cedar is attributable, in part, to the influence of minimum air temperature. The $\mathrm{P}_{\mathrm{n}}$ rates of both western redcedar and yellow-cedar decreased with a decline in the previous night minimum air temperature, though change was more rapid in western redcedar than yellow-cedar $\left(0.19\right.$ and $0.13 \mu \mathrm{mol} \mathrm{m}{ }^{-2} \mathrm{~s}^{-1}$ change in $\mathrm{P}_{\mathrm{n}}$ of western redcedar and yellow-cedar, respectively, for every $1{ }^{\circ} \mathrm{C}$ change in minimum air temperature) (Fig. 1). Western redcedar had higher $(P<0.05) \mathrm{P}_{\mathrm{n}}$ rates than yellow-cedar when minimum air temperature was above freezing. Field and laboratory studies have found low, but above freezing, air temperature can limit the photosynthetic process of conifers [31, 33, 34, 44, 47].

Freezing temperatures from $\sim 0$ to $-5{ }^{\circ} \mathrm{C}$ caused a further reduction, though not a complete stoppage, of photosynthetic capability in western redcedar and yellow-cedar (Fig. 1). The minimum air temperature at which $\mathrm{P}_{\mathrm{n}}$ declined to zero was estimated to be $-9.3{ }^{\circ} \mathrm{C}$ for western redcedar and $-12.2{ }^{\circ} \mathrm{C}$ for yellow-cedar. Western redcedar quickly recovers its photosynthetic capability after exposure to freezing temperatures as low as $-15^{\circ} \mathrm{C}$ when measured during January [23]. Winter season tolerance of photosynthetic capability is attributed to "hardening" characteristics of tree species growing in low-temperature climates [50]. Western redcedar and yellow-cedar have a high level of stress resistance (i.e., tolerance to both drought (western redcedar: [13], yellow-cedar: [15]) and freezing tolerance, see below) during the winter. These species photosynthetic systems have developed the capability to withstand mild freezing events during the winter, thereby replenishing carbon stores and offsetting the metabolic cost of retaining foliage throughout the winter.

In some instances during the late fall, winter and early spring, $\mathrm{P}_{\mathrm{n}}$ rates in western redcedar and yellow-cedar (data not shown) can reach levels comparable to those measured during active growth (western redcedar: [32]; yellow-cedar: [14]). High $\mathrm{P}_{\mathrm{n}}$ rates occurred when air temperatures reached unseasonably high values (e.g., minimum air temperature $>5.0^{\circ} \mathrm{C}$ : Fig. 1). Mid winter increases the photosynthetic rates of coniferous species occur when there are warm air temperature events [42, 43, 48, 50].

There was no difference in the $\mathrm{P}_{\mathrm{n}}$ response of populations for either western redcedar or yellow-cedar (Fig. 1). No comparable published work describes within species population response of $\mathrm{P}_{\mathrm{n}}$ to fall, winter and early spring temperature con-
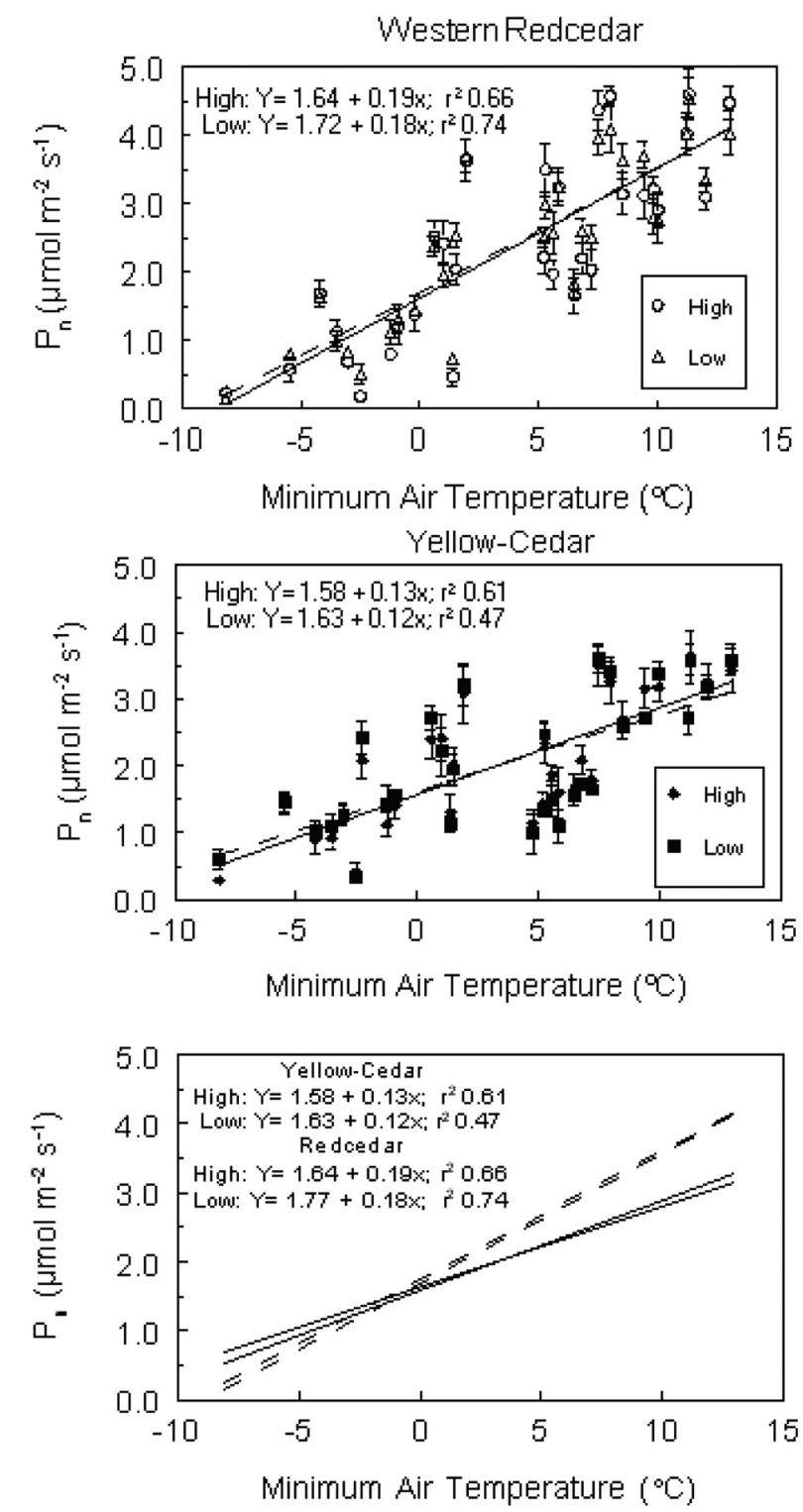

Figure 1. Changes in maximum net photosynthesis $\left(\mathrm{P}_{\mathrm{n}}\right)$ of western redcedar (low at $570 \mathrm{~m}$ and high at $900 \mathrm{~m}$ ) and yellow-cedar (low at $570 \mathrm{~m}$ and high at $1100 \mathrm{~m}$ ) populations to the previous night minimum air temperature throughout the fall, winter and early spring. The last figure shows the response of western red cedar (dashed lines) and yellow-cedar (solid lines).

ditions for these species. Studies on tree species have found that higher elevation seed-sources can have a higher $P_{n}$ response to lower temperature conditions $[11,29,46,51]$. The lack of population differences in western redcedar and yellow-cedar is most likely attributed to only a 300 to 500 m elevation separation for sample populations.

\subsection{Shoot growth}

Shoot growth had ceased in all populations of western redcedar and yellow-cedar by Julian day 308, and this corresponded to a decrease in mean air temperature to $4{ }^{\circ} \mathrm{C}$ (Fig. 2). 

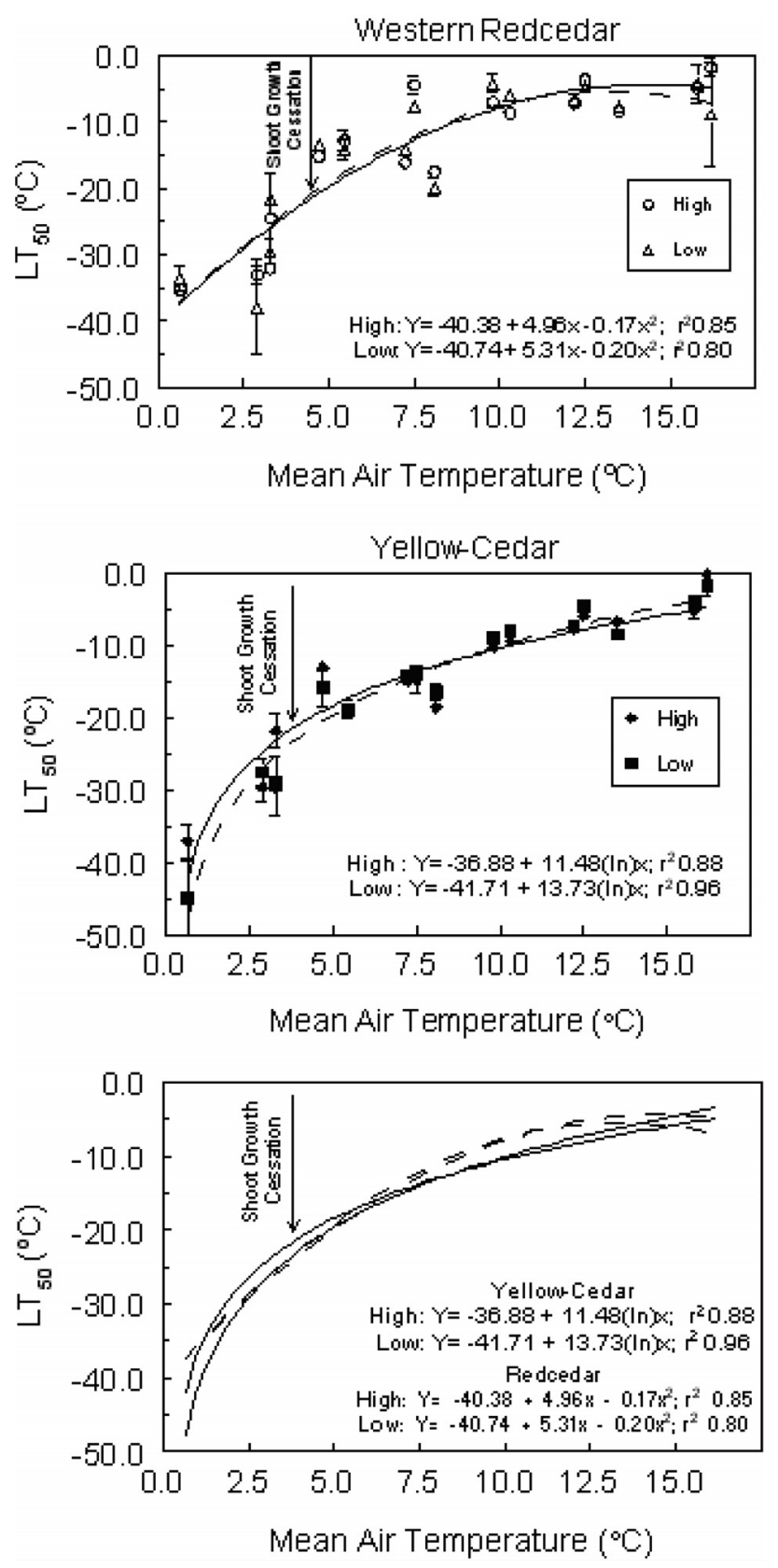

Figure 2. Changes in freezing tolerance $\left(\mathrm{LT}_{50}\right.$ is the freezing temperature resulting in 50\% foliage electrolyte leakage) of western redcedar (low at $570 \mathrm{~m}$ and high at $900 \mathrm{~m}$ ) and yellow-cedar (low at $570 \mathrm{~m}$ and high at $1100 \mathrm{~m}$ ) populations to mean air temperature (previous seven day average) in the fall. Arrows on the figure indicate the date when shoot growth cessation occurred in the fall for both species. The last figure shows the response of western red cedar (dashed lines) and yellow-cedar (solid lines).

No mitotic activity was detected in shoot tips of western redcedar and yellow-cedar at this point in time. Western redcedar is considered dormant when mitotic activity declines to zero [27]. Western redcedar and yellow-cedar have no fixed shoot growth periodicity and are adapted to an opportunistic form of growth [35]. These species have a growing season that can
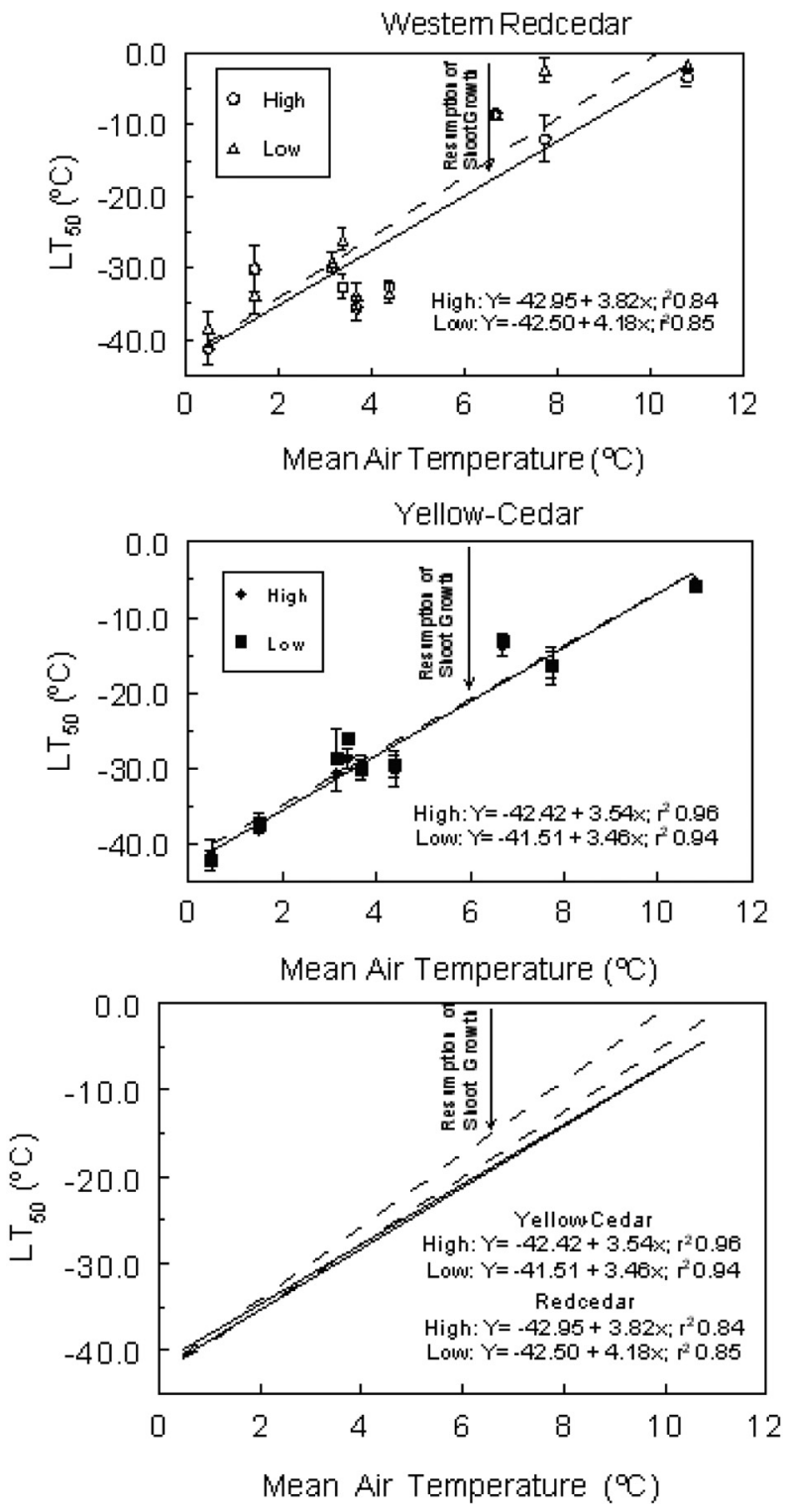

Figure 3. Changes in freezing tolerance $\left(\mathrm{LT}_{50}\right.$ is the freezing temperature resulting in 50\% foliage electrolyte leakage) of western redcedar (low at $570 \mathrm{~m}$ and high at $900 \mathrm{~m}$ ) and yellow-cedar (low at $570 \mathrm{~m}$ and high at $1100 \mathrm{~m}$ ) populations to mean air temperature (previous seven day average) in the winter and early spring. Arrows on the figure indicate the date when shoot growth resumed in the late winter for both species. The last figure shows the response of western redcedar (dashed lines) and yellow-cedar (solid lines).

extend into late fall as long as growing conditions are favorable [45]. Thus, it was assumed that western redcedar and yellowcedar had reached their seasonal period of inactive shoot growth after mean air temperature decreased to $4{ }^{\circ} \mathrm{C}$ in the fall.

Measurable shoot growth was detected in late winter by Julian day 72 after exposure to a mean air temperature of 6.0 to $6.5^{\circ} \mathrm{C}$ (Fig. 3). Both species and both populations for each species, resumed shoot growth at the same period of time. Conifers with buds become active primarily in response to rising temperatures in late winter and early spring [36]. 


\subsection{Freezing tolerance}

Freezing tolerance decreased during the fall, with a consistently high level of freezing tolerance during mid winter, followed by decreasing freezing tolerance in late winter and early spring (data not shown). This is the typical seasonal freezing tolerance pattern for both western redcedar $[9,13,21]$ and yellow-cedar [5, 22] in coastal forests of the Pacific Northwest.

Western redcedar and yellow-cedar both displayed a comparable fall decline in freezing tolerance. The $\mathrm{LT}_{50}$ values (i.e., freezing temperature at which $50 \%$ foliage electrolyte leakage occurred) of both western redcedar and yellow-cedar decreased as mean air temperature declined (Fig. 2). There was no difference in the $\mathrm{LT}_{50}$ response of populations for either species. In addition, both species had a similar decrease in $\mathrm{LT}_{50}$ values during the fall decline in air temperature.

Development of freezing tolerance in conifers normally is initiated in late summer and fall during acclimation to seasonal changes in photoperiod and temperature [41]. Freezing tolerance in western redcedar $[9,45]$ and yellow-cedar $[37,45]$ can be initiated by a decrease in photoperiod. The first stage of cold acclimation appears to result from exposure to short days while air temperature remains fairly high $\left(>10^{\circ} \mathrm{C}\right)$. In early fall, both western redcedar and yellow-cedar developed moderate levels of freezing tolerance when their shoot systems were still active which was related to a gradual decrease in mean air temperature (1.2 and $2.4{ }^{\circ} \mathrm{C}$ decrease in $\mathrm{LT}_{50}$ of western redcedar and yellow-cedar, respectively, for every $1{ }^{\circ} \mathrm{C}$ decline in mean air temperatures above $10^{\circ} \mathrm{C}$ ) (Fig. 2). In conifers that develop a bud, the cessation of shoot elongation and development of over winter buds is an indication of vegetative maturity [3] and is considered the first stage of fall acclimation to low temperatures $[30,54]$. At this point plants accumulate stored reserves to serve as an energy source for metabolic changes during the second stage of acclimation [41]. The second stage of acclimation occurs when plants are exposed to low fall temperatures, with freezing tolerance increasing rapidly and reaching a maximum level [3]. Both western redcedar and yellow-cedar are considered in a dormant state when growth has ceased and there is no detectable mitotic activity [27, 35]. Freezing tolerance increased at a greater rate in yellow-cedar than western redcedar when they were in an inactive state with the fall decrease in mean air temperature $\left(4.1\right.$ and $5.3{ }^{\circ} \mathrm{C}$ increase in freezing tolerance for western redcedar and yellow-cedar, respectively, for every $1{ }^{\circ} \mathrm{C}$ decline in mean air temperature below $4{ }^{\circ} \mathrm{C}$ ). Findings corroborate work showing that freezing tolerance develops rapidly in western redcedar $[13,45]$ and yellow-cedar $[5$, $20,21]$ exposed to lower winter air temperatures.

As air temperature increases in late winter and early spring, freezing tolerance decreases in both western redcedar and yellow-cedar. There was no difference in the $\mathrm{LT}_{50}$ response of populations for yellow-cedar, while the low population lost freezing tolerance at a faster rate $(P<0.05)$ than the high population for western red cedar (Fig. 3). Western redcedar low population lost freezing tolerance at a faster rate $(P<0.05)$ compared to yellow-cedar $\left(4.2^{\circ} \mathrm{C}\right.$ and $3.5^{\circ} \mathrm{C}$ increase in $\mathrm{LT}_{50}$ for western redcedar and yellow-cedar, respectively, for every $1{ }^{\circ} \mathrm{C}$ increase in mean air temperature) in late winter and early spring. Temperature is considered the primary environmental variable controlling the loss of freezing tolerance in late winter and early spring in yellow-cedar [20] and in conifer species, in general $[2,12,49,52]$.

Western redcedar had lower levels of freezing tolerance than yellow-cedar after the initiation of shoot growth, though the rate of loss was not affected by when their shoots had resumed growth. Increasing air temperature, along with an increasing photoperiod, interact to allow for the earliest possible bud activity that is compatible with the risk of damage due to frost [28]. It was recognized that both increasing temperature and photoperiod occurred during the late winter and early spring rapid loss of freezing tolerance, though their separate effects cannot be discerned in this field trial. A rapid loss of freezing tolerance occurs in yellow-cedar under the combination of increasing temperature and photoperiod [18, 19].

Freezing tolerance related traits are thought to be under relatively strong selection pressure, and that these traits are adaptive and under differential selection in different environments [1]. In this study, freezing tolerance was fairly similar for populations from within the elevational gradient where both species coexist. Reported work has found a weak elevational cline in seasonal freezing tolerance patterns of western redcedar [38] and yellow-cedar populations [21]. Other work on another indeterminate conifer species (Cupressus arizonica Greene) has also shown little variation along elevational cline in seasonal freezing tolerance [39]. The lack of difference among populations within species is most likely attributable to populations being separated by only $300 \mathrm{~m}$ to $500 \mathrm{~m}$ with the resultant gene flow decreasing potential selection effects on gene frequencies. As well, both species typically display less adaptive variation as compared to its sympatrics $[20,38]$.

\section{CONCLUSIONS}

Western redcedar and yellow-cedar were exposed to changing seasonal temperatures that are typically found under field conditions in coastal forests of the Pacific Northwest during the fall, winter and early spring period. Both western redcedar and yellow-cedar photosynthetic patterns during fall, winter and early spring were directly affected by minimum air temperatures. It appears that yellow-cedar retains a greater capacity for photosynthesis at low temperatures, while western redcedar has greater photosynthetic capacity at above freezing temperatures. Freezing tolerance patterns in the fall, winter and early spring are directly affected by changes in mean air temperature. Fall development of freezing tolerance was gradual prior to the cessation of shoot growth and more rapid after the cessation of shoot growth in both species. Both species acquire freezing tolerance in the fall at a very similar rate. Western redcedar loses freezing tolerance in the late winter and early spring at a more rapid rate than yellow-cedar. Furthermore, low elevation western redcedar appears to lose freezing tolerance much more rapidly in the spring than yellow-cedar. Populations from where both species coexist had fairly similar patterns of shoot growth, photosynthetic capability and freezing tolerance throughout the fall, winter and early spring period. The similarity in performance of western redcedar and yellow-cedar, and populations with each species, corroborates the generalist classification that has been given to these species. 
Acknowledgments: Support for this study came from a Forest Renewal B.C. program (No. HQ96440-RE) to John Russell with the British Columbia Ministry of Forests.

\section{REFERENCES}

[1] Aitken S.N., Hannerz M., Genecology and gene resource management strategies for conifer cold hardiness, in: Bigras F.J., Colombo S.J. (Eds.), Conifer Cold Hardiness, Kluwer Academic Publishers, The Netherlands, 2001, pp. 23-53.

[2] Aronsson A., Influence of photo- and thermoperiod on the initial stages of frost hardening and dehardening of phytotron-grown seedlings of Scots pine (Pinus silvestris L.) and Norway spruce (Picea abies (L.) Karst.), Stud. For. Suec. 128 (1975) 5-20.

[3] Burr K.E., The target seedling concept: bud dormancy and coldhardiness, in: Rose R., Campbell S.J., Landis T.D. (Eds.), Target Seedling Symposium: Proceedings of the Western Forest Nursery Associations, USDA For. Serv. Gen. Tech. Rep. RM-200, pp. 79-90.

[4] Bur K.E., Tinus R.W., Wallner S.J., King R.M., Comparison of three cold hardiness tests for conifer seedlings, Tree Physiol. 6 (1990) 351-369.

[5] Davradou M., Hawkins B.J., Effects of plantation location and population on the seasonal freezing tolerance of yellow-cedar (Chamaecyparis nootkatensis) stecklings, New For. 15 (1998) 77-88.

[6] Dexter S.T., Tottingham W.E., Graber L.F., Preliminary results in measuring the hardiness of plants, Plant Physiol. 5 (1930) 215-223.

[7] Dickmann D., Role of physiology in forest tree improvement, Silva. Fenn. 25 (1992) 248-256.

[8] Flint H.L., Boyce B.R., Beattie D.J., Index of injury - a useful expression of freezing injury to plant tissues as determined by the electrolytic method, Can. J. Plant Sci. 47 (1967) 229-230.

[9] Folk R.S., Grossnickle S.C., Major J.E., Arnott J.T., Influence of nursery culture on western redcedar. II. Freezing tolerance of fallplanted seedlings and morphological development of fall- and spring-planted seedlings, New For. 8 (1994) 231-247.

[10] Fowells H.A. (Ed.), Silvics of forest trees of the United States, USDA For. Serv. Ag. handbook, No. 271, 1965.

[11] Fryer J.H., Ledig F.T., Microevolution of the photosynthetic temperature optimum in relation to the elevational complex gradient, Can. J. Bot. 50 (1972) 1231-1235.

[12] Greer D.H., Stanley C.J., Regulation of the loss of frost hardiness in Pinus radiata by photoperiod and temperature, Plant Cell Environ. 8 (1985) 111-116.

[13] Grossnickle S.C., Relationship between freezing tolerance and shoot water relations of western redcedar, Tree Physiol. 11 (1992) 229-240.

[14] Grossnickle S.C., Russell J.H., Gas exchange processes of yellowcedar (Chamaecyparis nootkatensis (D. Don) Spach) in response to environmental variables, Can. J. Bot. 69 (1991) 2684-2691.

[15] Grossnickle S.C., Russell J.H., Changes in shoot water relations parameters of yellow-cedar (Chamaecyparis nootkatensis (D. Don) Spach) in response to environmental conditions, Can. J. Bot. 74 (1996) 31-39.

[16] Hall A.E., Mathematical models of plant water loss and plant water relations, in: Lange O.L., Nobel P.S., Osmond C.B., Ziegler H. (Eds.), Physiological Plant Ecology. II. Water Relations and Carbon Assimilation, Springer-Verlag, New York, NY, 1982, pp. 231-262.

[17] Harlow W.M., Harrar E.S., Textbook of dendrology, 5th ed. McGraw-Hill, 1969, 512 p.

[18] Hawkins B.J., Photoperiod and night frost influence the frost hardiness of Chamaecyparis nootkatensis clones, Can. J. For. Res. 23 (1993) 1408-1414.
[19] Hawkins B.J., McDonald S.E., Photoperiod influences dehardening of Chamaecyparis nootkatensis seedlings, Can. J. For. Res. 23 (1993) 2452-2454.

[20] Hawkins B.J., Russell J., Arnott J.T., Cold hardiness of yellowcedar (Chamaecyparis nootkatensis (D. Don) Spach), in: Bigras F.J., Colombo S.J. (Eds.), Conifer Cold Hardiness, Kluwer Academic Publishers, The Netherlands, 2001, pp. 531-554.

[21] Hawkins B.J., Russell J., Shortt R., Effect of population, environment, and maturation on frost hardiness of yellow-cedar (Chamaecyparis nootkatensis), Can. J. For. Res. 24 (1994) 945-953.

[22] Hawkins B.J., Henry G., Whittington J., Frost hardiness of Thuja plicata and Pseudotsuga menziesii seedlings when nutrient supply varies with season, Can. J. For Res. 25 (1995) 1509-1513.

[23] Hawkins B.J., Davradou M., Pier D., Shortt R., Frost hardiness and winter photosynthesis of Thuja plicata and Pseudotsuga menziesii seedlings grown at three rates of nitrogen and phosphorus supply, Can. J. For. Res. 24 (1994) 18-28.

[24] Huitema B.E., The Analysis of Covariance and Alternatives, John Wiley \& Sons, New York, 1980.

[25] Johansen D.A., Plant Microtechnique, McGraw-Hill, 1940.

[26] Kleinbaum D.G., Kupper L.L., Muller K.E., Applied regression analysis and other multivariable methods, 2nd ed., PWS-Kent Publishing Co. Boston, 1998.

[27] Krasowski M.J., Owens J.N., Growth and morphology of western redcedar seedlings as affected by photoperiod and moisture stress, Can J. For. Res. 21 (1991) 340-352.

[28] Lavender D.P., Sweet G.B., Zaerr J.B., Hermann R.K., Spring shoot growth in Douglas-fir may be initiated by gibberellins exported from the roots, Science, 182 (1973) 838-839.

[29] Ledig F.T., Korbobo D.R., Adaptation of sugar maple populations along altitudinal gradients: photosynthesis, respiration, and specific leaf weight, Am. J. Bot. 70 (1983) 256-265.

[30] Levitt J., Response of Plants to Environmental Stress. Vol. I. Chilling, Freezing and High Temperature Stress, Academic Press, New York, 1980.

[31] Ludlow M.M., Jarvis P.G., Photosynthesis in Sitka spruce (Picea sitchensis (Bong.) Carr.), J. Appl. Ecol. 8 (1971) 925-954.

[32] Major J.E., Grossnickle S.C., Folk R.S., Arnott J.T., Influence of nursery culture on western redcedar. I. Measurement of seedling attributes before fall and spring planting, New For. 8 (1994) $211-$ 229.

[33] Neilson R.E., Jarvis P.G., Photosynthesis in Sitka spruce (Picea sitchensis (Bong.) Carr). VI. Response of stomata to temperature, J. Appl. Ecol. 12 (1976) 879-891.

[34] Öquist G., Effects of low temperature on photosynthesis, Plant Cell Environ. 6 (1983) 281-300.

[35] Owens J.N., Moder M., Reproductive cycles of western redcedar and yellow-cedar, Information Services Branch, British Columbia Ministry of Forests, Mesachie Lake, B.C., 1984.

[36] Perry T.O., Dormancy of trees in winter, Science 171 (1971) 29-36.

[37] Puttonen P., Arnott J.T., Influence of photoperiod and temperature on growth, gas exchange, and cold hardiness of yellow cypress (Chamaecyparis nootkatensis (D. Don) Spach) stecklings, Can. J. For. Res. 24 (1994) 1608-1616.

[38] Rehfeldt G.E., Genetic structure of western red cedar populations in the Interior West, Can. J. For. Res. 24 (1994) 670-680.

[39] Rehfeldt G.E., Quantitative analyses of the genetic structure of closely related conifers with disparate distributions and demographics: the Cupressus arizonica complex, Am. J. Bot. 84 (1997) 190-200.

[40] Russell J.H., Grossnickle S.C., Ferguson C., Carson D.W., Yellowcedar stecklings: Nursery production and field performance, FRDA Rep. 148, 1990, 20 p. 
[41] Sakai A., Larcher W., Frost Survival of Plants, Ecological Studies Vol. 62, Springer-Verlag, New York, 1987.

[42] Schaberg P.G., Wilkinson R.C., Shane J.B., Donnelly J.R., Cali P.F., Winter photosynthesis of red spruce from three Vermont seed sources, Tree Physiol. 15 (1995) 345-350.

[43] Schaberg P.G., Shane J.B., Hawley G.J., Strimbeck G.R., DeHayes D.H., Cali P.F., Donnelly J.R., Physiological changes in red spruce during a simulated winter thaw, Tree Physiol. 16 (1996) 567-574.

[44] Schwarz P.A., Fahey T.J., Dawson T.E., Seasonal air and soil temperature effects on photosynthesis in red spruce (Picea rubens) saplings, Tree Physiol. 17 (1997) 187-194.

[45] Silim N., Lavender D.P., Seasonal patterns and environmental regulation of frost hardiness in shoots of seedlings of Thuja plicata, Chamaecyparis nootkatensis, and Picea glauca, Can. J. Bot. 72 (1994) 309-316.

[46] Slatyer R.O., Ferrar P.J., Altitudinal variation in the photosynthesis characteristics of snow gum, Eucalyptus pauciflora Sieb. Ex Spreng. II. Effects of growth temperature under controlled conditions, Aust. J. Plant Physiol. 4 (1977) 289-299.

[47] Strand M., Lundmark T., Söderbergh I., Mellander P.E., Impacts of seasonal air and soil temperatures on photosynthesis in Scots pine trees, Tree Physiol. 22 (2002) 839-847.
[48] Strimbeck G.R., Schaberg P.G., DeHayes D.H., Shane J.B., Hawley G.J., Midwinter dehardening of montane red spruce during a natural thaw, Can. J. For. Res. 25 (1995) 2040-2044.

[49] Timmis R., Flewelling J., Talbert C., Frost injury prediction model for Douglas-fir seedlings in the Pacific Northwest, Tree Physiol. 14 (1994) 855-869.

[50] Tranquillini W., Physiological Ecology of the Alpine Timberline, Springer-Verlag, N.Y., 1979.

[51] Tranquillini W., Havranek W.M., Influence of temperature on photosynthesis in spruce provenances from different altitudes, in: Turner H., Tranquillini W. (Eds.), Establishment and Tending of Subalpine Forest: Research and Management, Proc. 3rd IUFRO Workshop P 1.07-00 Eidg. Anstl. Forstl. Versuchswes. Ber. 270, 1984, pp. 41-51.

[52] Van den Driessche R., Influence of moisture supply, temperature and light on frost-hardiness changes in Douglas-fir seedlings, Can. J. Bot. 47 (1969) 1765-1772.

[53] Waring R.H., Franklin J.F., Evergreen coniferous forests of the Pacific Northwest, Science, 204 (1979) 1380-1386.

[54] Weiser C.J., Cold resistance and injury in woody plants, Science, 169 (1970) 1269-1277.

[55] Wilkinson L., Hill M., Welna J.P., Birkenbeuel G.K., Systat ${ }^{\circledR}$ for windows (Version 5.0): Statistics, SPSS, Inc., Chicago, 1992.

To access this journal online: www.edpsciences.org 